\title{
The first record of Micaria bonneti (Aranei: Gnaphosidae) in Mongolia
}

\section{Первая находка Micaria bonneti (Aranei: Gnaphosidae) в Монголии}

\author{
Yuri M. Marusik \\ Ю.М. Марусик
}

Institute for Biological Problems of the North RAS, Portovaya Str. 18, Magadan, Russia. E-mail: yurmar@mail.ru Zoology \& Entomology, University of the Free State, Bloemfontein 9300, South Africa Zoological Museum, Biodiversity Unit, FI-20014 University of Turku, Finland.

Институт биологический проблем Севера, ДВО РАН, Портовая 18, Магадан 685000.

KEY WORDS: Araneae, spider, China, Tuva, new record, accessorial gland, receptacular gland, type locality.

КЛЮЧЕВЫЕ СЛОВА: Araneae, паук, Китай, Тува, новая находка, вспомогательная железа, железа рецептакулы, типовое местообитание.

ABSTRACT: Micaria bonneti Schenkel, 1963, a species known only from China, is reported from Mongolia. Conspecificity of this species with specimens from Hubei Province and the central part of Inner Mongolia (type locality) is doubtful. M. mongunica Danilov, 1997, a species known by the holotype female from Western Tuva, is most likely a junior synonym of M. bonneti. Erroneous data about the type locality of $M$. bonneti is corrected. The epigyne of $M$. bonneti is illustrated in detail, and its structure is discussed.

How to cite this article: Marusik Yu.M. 2018. The first record of Micaria bonneti (Aranei: Gnaphosidae) in Mongolia // Arthropoda Selecta. Vol.27. No.4. P.335-338. doi: 10.15298/arthsel. 27.4.09

PЕЗЮME: Micaria bonneti Schenkel, 1963, вид ранее известный только из Китая, впервые отмечен в Монголии. Конспецифичность популяций из провинции Хебей и центральной части Внутренней Монголии (типовое местообитание) ставится под сомнение. Micaria mongunica Danilov, 1997 известная по голотипу из Западной Тувы возможно является младшим синонимом M. bonneti. Уточнено типовое местообитание M. bonneti. Эпигина M. bonneti детально проиллюстрирована, обсуждаются детали её строения.

\section{Introduction}

While identifying spiders from Mongolia, I found four specimens of gnaphosids that resembled by light coloration Synaphosus Platnick et Shadab, 1980 or Leptodrassex Murphy, 2007; however, the epigynes indicated that they belong to Micaria Westring, 1851. Most Micaria have dark areas on some parts of the body and are covered with numerous, flat iridescent scales. Study of these specimens reveal that they be- long to Micaria bonneti Schenkel, 1963, a species only known from females, distributed in Gansu, Inner Mongolia and Hebei Provinces of China [Song et al., 2004; $\mathrm{Li}$, Lin, 2016]. A literature search revealed that the record of this species from Gansu is incorrect, as the specimen referred to in Schenkel [1963] is actually from Inner Mongolia (type locality). Additionally, the record from Hebei may refer to another species, and $M$. bonneti may be a senior synonym of $M$. mongunica Danilov, 1997, a species only known from Tuva. The goals of this paper are to provide detailed illustrations of $M$. bonneti based on the specimens from Mongolia and to discuss the distribution, and importance of the accessorial gland in distinguishing Micaria species.

\section{Material and methods}

Specimens were photographed with a Canon EOS 7D camera attached to an Olympus SZX16 stereomicroscope and Pro-Microscan camera attached to the Olympus BH-2. Digital images were montaged using CombineZP and Helicon focus 3.10 image stacking software. Epigynes were cleared in a $\mathrm{KOH} /$ water solution until soft tissues were dissolved. Material studied here will be shared between the Zoological Museum of Moscow State University and the Hungarian Museum of Natural History (Budapest).

\section{Taxonomy}

Micaria bonneti Schenkel, 1963 Figs 1-8, Map 1.

M. b. Schenkel, 1963: 274, f. 155 ().

M. b.: Zhang, 1987: 182, f. 153.1-3 (ㅇ) .

M. b.: Danilov, 1997a: 114, f. 1C-D (+).

M. b.: Song et al., 1999: 452, f. 264A (+).

M. b.: Song et al., 2001: 347, f. 224A-B (+). 

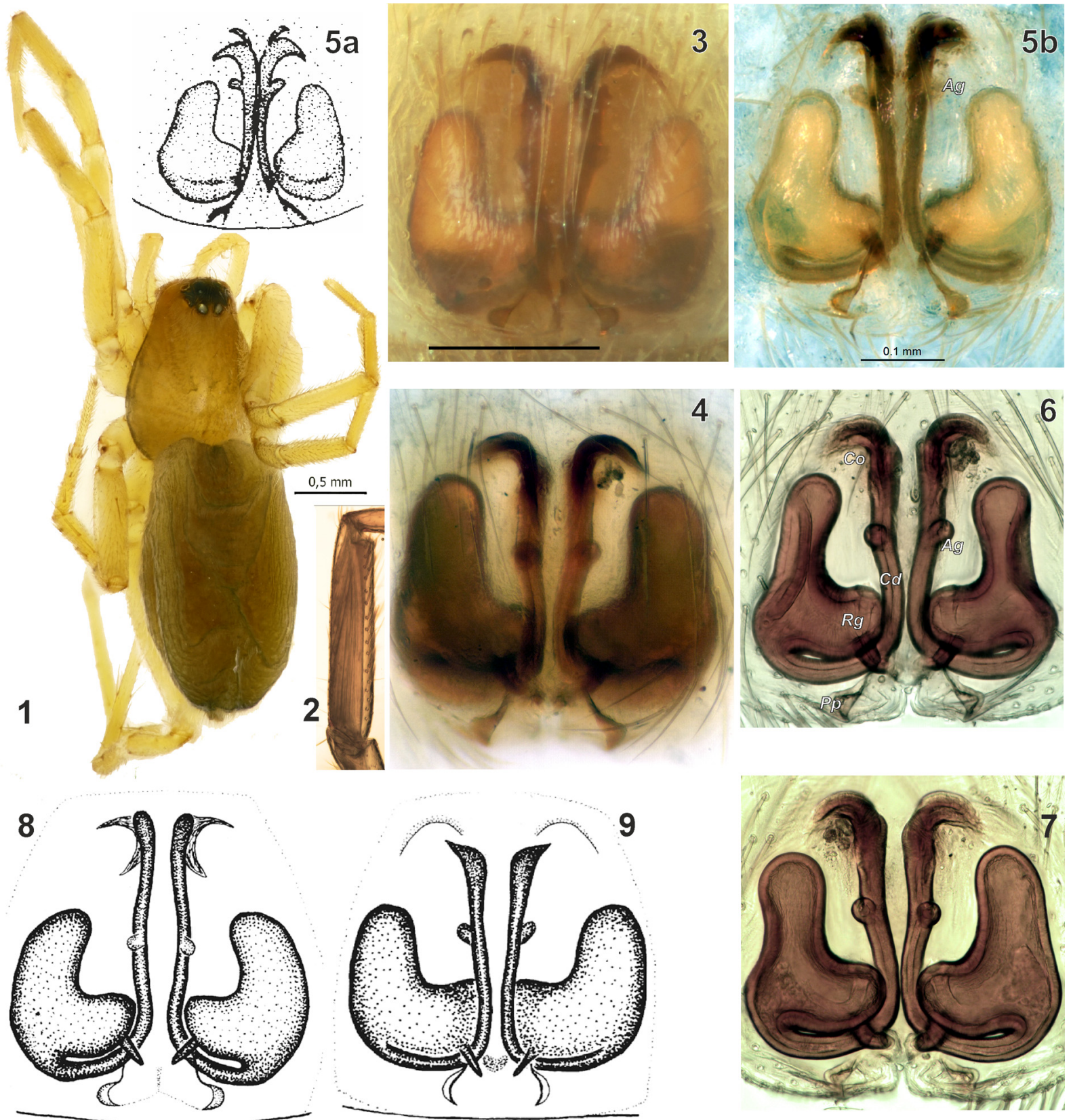

Figs 1-5. Habitus and epigyne of Micaria bonneti (1-8) and M. mongunica (9). 1 - habitus, dorsal; 2 - tibia I, prolateral; 3, 5 intact epigyne, ventral; 4, 5b, 6-9 - dissected epigyne, ventral. 1-4, 6-7 - specimen from Mongolia; 5a - specimen from Hubei, after Zhang (1987); $5 \mathrm{~b}$ - specimen from Hubei (photo by Zhang Feng); 8-9 - holotypes (after Danilov, 1997). Scale 0.2 mm (Figs.3-4). gland.

Abbreviations: $\mathrm{Ag}$ - accessorial gland, $\mathrm{Cd}$ - copulatory duct, $\mathrm{Co}$ - copulatory opening, $\mathrm{Pp}$ - posterior pocket, $\mathrm{Rg}$ - receptacular

Рис 1-5. Габитус и эпигина Micaria bonneti (1-8) и M. mongunica (9). 1 - габитус, сверху; 2 - голень I, спереди; 3,5 интактная эпигина, снизу; 4, 5b, 6-9- отпрепарированная эпигина, снизу. 1-4, 6-7 - экземпляры из Монголии; 5a - самка из провинции Хэбэй, по Zhang [1987]; 5b - самка из провинции Хэбэй (фото Zhang Feng); 8-9 — голотипы (по Danilov [1997]). Масштаб 0,2 мм (рис.3-4).

Сокращения: $A g-$ вспомогательная железа, $C d-$ копулятивная канал, $C o-$ копулятивное отверстие, $P p-$ задний карман, $R g$ — железа рецептакулы.

M. b.: Song et al., 2004: 168, f. 98A-B (+).

NOTE: Figures published by Song et al. [1999, 2001, 2004] are copies of Danilov's [1997] figures.

MATERIAL EXAMINED: 4 OP, MONGOLIA, Central Aimag: $12 \mathrm{~km} \mathrm{~S}$ von Somon Bajanbaraat, $1380 \mathrm{~m}, 8 . V I .1967 .-\mathrm{An}$ einem sandigen, steinigen Berghang 10 Ethylenglycol-Bodenfallen ausgegraben. Aufgenommen am 14.VII.1967 (Z. Kaszab).

DIAGNOSIS. This species differs from other Micaria species known from the region by light colouration, lack of scales covering the body and the shape of the epigyne. 


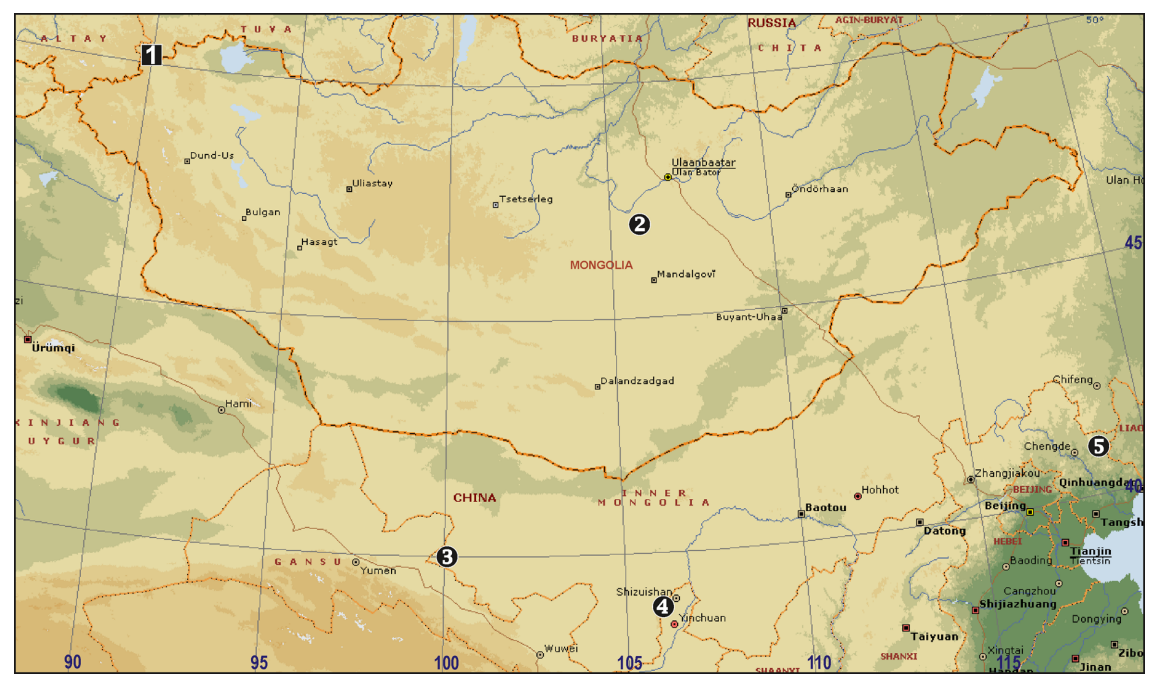

Map 1. Distribution records of Micaria mongunica (1) and M. bonneti (2-5). 1, 3 - type localities; 2 - new record from Mongolia; 4 - Inner Mongolia record from Song et al. [2004]; 5 - unspecified record from Hebei Province.

Карта 1. Точки находок Micaria mongunica (1) и M. bonneti (2-5). 1, 3 - типовые местообитания; 2 - новая находка в Монголии; 4 - находка во Внутренней Монголии (по Song et al. [2004]); 5 - находка в провинции Хэбэй без указания конкретного локалитета.

Unlike most Micaria, it has globular accessorial glands on copulatory ducts. Three species that occur in China, $M$. tuvensis Danilov, 1993, M. marusiki Zhang, Song et Zhu, 2001 and M. pulicaria (Sundevall, 1831), also have glands associated with the copulatory ducts, but they are digitiform rather than globular. M. bonneti is most similar to M. mongunica Danilov, 1997 from Tuva. These two species have some differences in the shape of the copulatory openings (see Danilov, 1997) but have the same colouration. Also, the receptacles, copulatory ducts and their glands are the same shape and, thus, the two species are likely conspecific.

DESCRIPTION. A description of the general morphology, including leg measurements, is provided by Song et al. [2004]. The tibia, metatarsus and tarsus of legs I and II have paired ventral rows of setae (Fig. 2). The epigyne is as in Figs 3-8; the epigynal plate is as long as wide; fovea absent, copulatory openings $(\mathrm{Co})$ located on the anterior edge of the plate, with a semi-circular sclerotized edge, separated by a septum that is less than one diameter of the pocket; posterior pockets $(P p)$ separated slightly more than the anterior ones; receptacles elongate ovals, bent at a right angle, with the vertical part about 1.7 times longer than horizontal part, and the mesal part of the receptacle with a distinct gland $(R g)$; copulatory ducts $(C d)$ long, parallel and almost touching anteriorly, diverging posteriorly; copulatory ducts with globular accessorial gland $(A g)$.

COMMENTS. The holotype female illustrated by $\mathrm{Da}-$ nilov [1997] has shorter receptacles with equally long horizontal and vertical parts. All specimens from Mongolia have receptacles of the same length, as shown in Figs 6-7. The epigyne of M. mongunica described from Tuva (Fig. 9) is almost the same as that of the holotype of $M$. bonneti (Fig. 8 ), differing slightly in the shape of the copulatory openings. The shape of the receptacles, copulatory ducts and posterior pockets are the same, and the location of accessorial glands are equivalent in the two species. Additionally, the general pattern and size of the body and legs are the same. Therefore, $M$. mongunica may be a junior synonym of $M$. bonneti.
Judging from the anterior position of the accessorial glands shown by Zhang [1987: figs $153.2-3$ and Fig. 4] in the specimen from Hebei, this specimen may belong to a separate species. Accessorial glands are not properly documented in many Micaria species, but it seems they are present in most (cf. Miller, 1967; Wunderlich, 1979; Marusik, Omelko, 2017). The position and shape of these glands can be used for distinguishing sibling species of Micaria. Receptacular glands are schematically shown only by Miller [1967] and only for a few species, although they may be present in several species.

DISTRIBUTION (Map 1). Li \& Lin [2016] indicate the distribution of $M$. bonneti as Hebei, Inner Mongolia and Gansu. Schenkel [1963] provided a list of all localities and listed "Fluss Bardun" among the Inner Mongolia localities; however, in the text dealing with a description of the new species he indicated "Fluss Bardun, Kansu". According to Potanin [1893], the Bardun River is located in Inner Mongolia, and therefore all references to Gansu Province are based on a lapsus in Schenkel [1963]. The exact type locality was located in the expedition description and map given in Patanin [1893].

\section{Acknowledgements}

I thank Ilari Sääksjärvi and Seppo Koponen (Turku, Finland) for allowing me to use museum facilities and Feng Zhang for providing Fig.5b. Figures from Zhang [1987] and Danilov [1997] are reproduced with the permission of the publishers. The English of the final draft was kindly checked by Sarah Crews (San Francisco, USA).

\section{References}

Danilov S.N. 1997. New data on the spider genus Micaria Westring, 1851 in Asia (Aranei Gnaphosidae). Arthropoda Selecta. Vol.5 (for 1996). No.3/4. P.113-116.

Li S.Q., Lin Y.C. 2016. [Species Catalogue of China. Vol.3 Animalia. Invertebrata (I) Arachnida: Araneae]. Beijing: Science Press. 578 pp. [in Chinese] 
Marusik Yu.M., Omelko M.M. 2017. Redescription of Micaria beaufortia (Araneae, Gnaphosidae), with notes on Afrotropical Micaria // Zootaxa. Vol.4294. No.4. P.462-470. DOI: https://doi.org/10.11646/zootaxa.4294.4.5

Miller F. 1967. Studien über die Kopulationsorgane der Spinnengattung Zelotes, Micaria, Robertus und Dipoena nebst Beschreibung einiger neuen oder unvollkommen bekannten Spinnenarten // Př́rodovědné práce ústavů Československé Akademie Věd v Brně (N.S.). Bd.1. S.251-298.

Potanin G.N. 1893. [The Tangut-Tibetan borderlands of China and Central Mongolia]. Saint-Petersburg: Royal Russian Geographical Society. Vol.2. 567 pp. [In Russian]

Schenkel E. 1963. Ostasiatische Spinnen aus dem Muséum d'Histoire naturelle de Paris // Mémoires du Muséum National d'Histoire Naturelle de Paris. Sér.A, Zool. T.25. P.1-481.
Song D.X., Zhu M.S., Chen J. 1999. The Spiders of China. Hebei University of Science and Technology Publishing House. 640 pp.

Song D.X., Zhu M.S., Chen J. 2001. The Fauna of Hebei, China: Araneae. Shijiazhuang: Hebei University of Science and Technology Publishing House. 510 pp.

Song D.X., Zhu M.S., Zhang F. 2004. [Fauna Sinica: Invertebrata. Vol.39: Arachnida: Araneae: Gnaphosidae]. Beijing: Science Press. 362 pp. [in Chinese]

Zhang W.S. (ed.). 1987. [Farm spiders from Hebei Province]. Hebei University of Science and Technology Press. 299 pp. [in Chinese]

Responsible editor K.G. Mikhailov 